\title{
Review of Fabrication Methods, Physical Properties, and Applications of Nanostructured Copper Oxides Formed via Electrochemical Oxidation
}

\author{
Wojciech J. Stepniowski ${ }^{1,2, *}$ and Wojciech Z. Misiolek ${ }^{1}$ (iD) \\ 1 Materials Science and Engineering Department \& Loewy Institute, Lehigh University, 5 East Packer Ave., \\ Bethlehem, PA 18015, USA; wzm2@lehigh.edu \\ 2 Department of Advanced Materials and Technologies, Faculty of Advanced Technology and Chemistry, \\ Military University of Technology, Urbanowicza 2 Str., 00-908 Warszawa, Poland \\ * Correspondence: wos218@lehigh.edu or wojciech.stepniowski@wat.edu.pl; Tel.: +1-484-516-6544
}

Received: 31 March 2018; Accepted: 24 May 2018; Published: 29 May 2018

\begin{abstract}
Typically, anodic oxidation of metals results in the formation of hexagonally arranged nanoporous or nanotubular oxide, with a specific oxidation state of the transition metal. Recently, the majority of transition metals have been anodized; however, the formation of copper oxides by electrochemical oxidation is yet unexplored and offers numerous, unique properties and applications. Nanowires formed by copper electrochemical oxidation are crystalline and composed of cuprous $(\mathrm{CuO})$ or cupric oxide $\left(\mathrm{Cu}_{2} \mathrm{O}\right)$, bringing varied physical and chemical properties to the nanostructured morphology and different band gaps: 1.44 and $2.22 \mathrm{eV}$, respectively. According to its Pourbaix (potential-pH) diagram, the passivity of copper occurs at ambient and alkaline $\mathrm{pH}$. In order to grow oxide nanostructures on copper, alkaline electrolytes like $\mathrm{NaOH}$ and $\mathrm{KOH}$ are used. To date, no systemic study has yet been reported on the influence of the operating conditions, such as the type of electrolyte, its temperature, and applied potential, on the morphology of the grown nanostructures. However, the numerous reports gathered in this paper will provide a certain view on the matter. After passivation, the formed nanostructures can be also post-treated. Post-treatments employ calcinations or chemical reactions, including the chemical reduction of the grown oxides. Nanostructures made of $\mathrm{CuO}$ or $\mathrm{Cu}_{2} \mathrm{O}$ have a broad range of potential applications. On one hand, with the use of surface morphology, the wetting contact angle is tuned. On the other hand, the chemical composition (pure $\mathrm{Cu}_{2} \mathrm{O}$ ) and high surface area make such materials attractive for renewable energy harvesting, including water splitting. While compared to other fabrication techniques, self-organized anodization is a facile, easy to scale-up, time-efficient approach, providing high-aspect ratio one-dimensional (1D) nanostructures. Despite these advantages, there are still numerous challenges that have to be faced, including the strict control of the chemical composition and morphology of the grown nanostructures, their uniformity, and understanding the mechanism of their growth.
\end{abstract}

Keywords: anodization; copper oxides; nanostructures; passivation; nanowires; nanoneedles; band gap

\section{Introduction}

Nanostructured anodic oxides have attracted the attention of researchers due to their ease of fabrication and tailored ordered morphology on the nanometric scale. What is more, the resulting chemical and physical properties lead to numerous potential applications [1]. The most frequently studied anodic oxides are hexagonally arranged anodic aluminum oxide (AAO) [1] and nanoporous or nanotubular anodic titanium oxide (ATO) [2]. Intensive research on those two nanostructured materials 
has incited significant progress in: electrochemical and optical sensing [3,4], nanofabrication [5], photonic crystals [6], information optical coding [7], filtration and kidney dialysis [8], drug releasing platforms [9], biomaterials performance [10], renewable energy harvesting [11,12], the removal of greenhouse gases [13], magnetic materials [14], surface-enhanced Raman spectroscopy [15], plasmonic materials [16], structural color generation [17], tunable contact angle surfaces [18,19], and tunable band gap materials [20].

Currently, the majority of transition metals have been tested as substrates for anodizing. Researchers have obtained nanostructured anodic oxides as the result of the electrochemical oxidation of: W [21,22], Sn [23], Zr [24,25], Zn [26,27], Nb [28,29], Fe [30], and FeAl [20,31]. The majority of the nanostructures obtained by transition metals anodization are composed of oxide, where the metallic element is at one fixed oxidation state. Furthermore, almost all of the oxides are nanoporous or nanotubular. So far, the only reported exception is anodically grown $\mathrm{ZnO}$ : in this case, the grown oxide is made of nanowires [26,27].

Another promising metal for oxide nanostructures fabrication via self-organized anodization is copper. Copper forms two oxides, namely cuprous oxide $\mathrm{Cu}_{2} \mathrm{O}$ and cupric oxide, $\mathrm{CuO}$, as well as their mixtures in various phases such as copper-rich $\mathrm{Cu}_{4} \mathrm{O}_{3}$ [32]. A demand for the simple synthesis of copper oxides' nanostructures is a result of the electronic properties of $\mathrm{Cu}_{2} \mathrm{O}, \mathrm{CuO}$, and $\mathrm{Cu}_{4} \mathrm{O}_{3}$. $\mathrm{CuO}$ is reported to be a p-type semiconductor with a band gap in the range from 1.2 to $2.16 \mathrm{eV}$, depending on the nature of the band gap (direct, or indirect), doping, morphology, and crystal size [32]. For CuO nanostructures, the smaller the size of the structure, the greater the band gap, observed as a blue shift in the spectrum. It is worth noting that Bohr's radius for $\mathrm{CuO}$ is ca. $6.6 \mathrm{~nm}$, thus below this size a strong quantum confinement $(\mathrm{QC})$ is observed [32] (nevertheless, $\mathrm{QC}$ is also observed above $6.6 \mathrm{~nm}$, although the phenomenon is much weaker). $\mathrm{Cu}_{2} \mathrm{O}$ is also a p-type semiconductor with a band gap over $2.1 \mathrm{eV}$ [32]. However, also in this case, due to the QC, the band gap can be engineered and controlled during the manufacturing process. For example, a decrease of $\mathrm{Cu}_{2} \mathrm{O}$ film thickness from 5.4 to $0.75 \mathrm{~nm}$ increases the band gap from 2.6 to $3.8 \mathrm{eV}$ [33]. Additionally, according to Musselman et al., $\mathrm{Cu}_{2} \mathrm{O}$, due to the band gap value around $2.0 \mathrm{eV}$ and theoretical maximum power conversion efficiency of approximately $20 \%$ (PCE), is suitable for applications in heterojunction solar cells [34].

There are numerous methods of $\mathrm{Cu}_{2} \mathrm{O}$ and $\mathrm{CuO}$ nanostructures fabrication, employing diverse chemical methods including micelle-assisted precipitation, sol-gel methods, and high-temperature annealing in an oxidative atmosphere. The formation of a wide range of nanostructures such as nanospheres, nanoflowers, leaf-shaped nanocrystals, nanorings, nanoribbons, multi-pod nanocrystals, etc. has been already reported and broad reviews reporting the state-of-the-art have been published $[35,36]$. Furthermore, this variety of nanostructures with high surface-to-bulk atom ratios has triggered research on numerous applications of $\mathrm{Cu}_{2} \mathrm{O}$ and $\mathrm{CuO}$ nanostructures, such as high-surface area electrode materials in batteries, photocatalysts in water purification systems, carbon dioxide reduction and water splitting, high-contact angle functional surfaces, gas sensors, infrared radiation sensors, etc. [35,36].

However, the anodization of copper, leading to the formation of nanostructures, has not been as intensively explored as other methods and was not even included in the numerous review reports focusing on the formation of cupric and cuprous oxide nanostructures. However, copper anodization may bring unexpected benefits in terms of morphology control, the formation of high-aspect ratio nanostructures, and their doping. Morphological features of nanostructured anodic oxides are tailored by operating conditions. For example, the pore diameter and intepore distance of anodic alumina and titania are linear functions of the applied voltage $[1,2,20]$. Additionally, electrochemical in situ doping of anodic oxides, due to the application of various additives in the electrolyte, allows one to dope the growing nanostructures [37]. Therefore, self-organized anodization seems to be a promising method in copper oxides formation, providing high-surface area nanostructures with a band gap tunable by operating conditions (size of the nanostructures) and chemical composition (in situ doping). Per analogiam to the anodization of $\mathrm{Al}$ and $\mathrm{Ti}$ [1-37], it can be expected that the morphology of the nanostructures formed by copper anodization can be tailored after the optimization of the operating 
conditions. Moreover, recent advances in $\mathrm{Al}$ and Ti anodization, as well as recent high-tech applications, may provide some inspiration for electrochemical copper oxidation.

\section{Passivation of Copper}

Pourbaix diagrams (potential vs. $\mathrm{pH}$ diagram) provide key information for understanding the electrochemical oxidation of metals. According to the Pourbaix diagram for copper, it is apparent that the most suitable electrolytes for copper anodization are the alkaline ones (solutions of bases like $\mathrm{NaOH}, \mathrm{KOH}$, but also salts with alkaline hydrolysis like carbonates and bicarbonates of potassium and sodium, not researched yet as potential copper anodizing electrolytes) (Figure 1) [38]. It is also noticeable that electrochemical oxidation may lead to the formation of oxides like $\mathrm{Cu}_{2} \mathrm{O}$ (lower potentials) and $\mathrm{CuO}$ (greater potentials), as well as cupric hydroxide $\mathrm{Cu}(\mathrm{OH})_{2}$ and water-soluble coordination anions with hydroxyl ligands, namely $\mathrm{Cu}(\mathrm{OH})_{3}{ }^{-}$and $\mathrm{Cu}(\mathrm{OH})_{4}{ }^{2-}$. For anodizing, the minimal solubility of $\mathrm{Cu}_{2} \mathrm{O}$ in water is at a $\mathrm{pH}$ range from 7.5 to 8.0 [38]. It is also worth noting that the as-obtained anodic oxides formed on copper are crystalline, while other anodic oxides, like titania or alumina, are amorphous. The formation of crystalline phases in anodic alumina or titania requires annealing after the anodization.
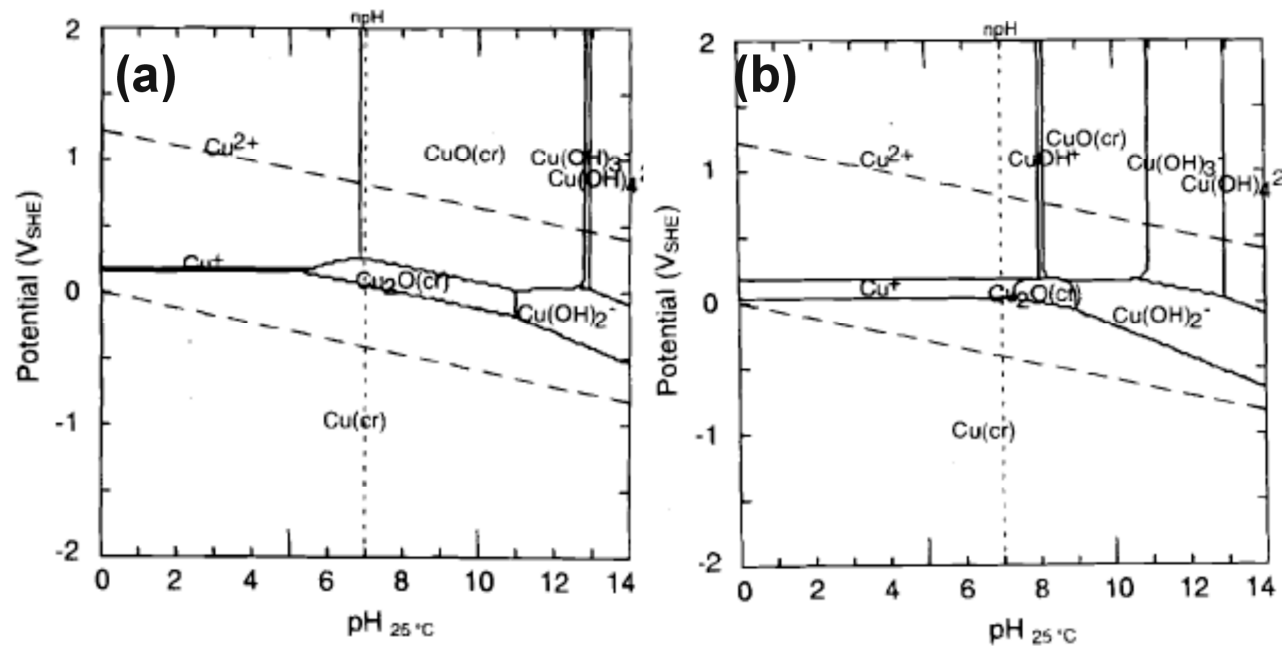

Figure 1. Pourbaix diagram for copper at $25^{\circ} \mathrm{C}$ for total copper species concentration in a solution equal to $10^{-6} \mathrm{~mol} / \mathrm{L} \mathrm{(a)} \mathrm{and} 10^{-8} \mathrm{~mol} / \mathrm{L} \mathrm{(b)}$. Reproduced with permission from [38]. Electrochemical Society, 1997.

Due to the formation of two copper oxides and the formation of soluble coordination ions, the mechanism of copper anodization is much more complex than in the case of other oxides, like AAO. Gennero de Chiavlo et al. analyzed the oxidation of copper only to the $\mathrm{Cu}^{+}$oxidation state and, already at this stage, the occurring phenomena are complex [39]. According to the chemical reactions, first copper oxidizes and forms metastable $\mathrm{CuOH}$ on the $\mathrm{Cu}$ surface (1):

$$
\mathrm{Cu}+\mathrm{OH}^{-} \rightarrow \mathrm{CuOH}+\overline{\mathrm{e}}
$$

Next, cuprous hydroxide, $\mathrm{CuOH}$, may react in two ways, either forming solid $\mathrm{Cu}_{2} \mathrm{O}$ (2):

$$
2 \mathrm{CuOH} \rightarrow \mathrm{Cu}_{2} \mathrm{O}+\mathrm{H}_{2} \mathrm{O}
$$

Or bonding the hydroxyl group and forming water-soluble $\mathrm{Cu}_{2} \mathrm{O}_{2} \mathrm{H}^{-}(3)$ :

$$
2 \mathrm{CuOH}+\mathrm{OH}^{-} \rightarrow \mathrm{Cu}_{2} \mathrm{O}_{2} \mathrm{H}^{-}+\mathrm{H}_{2} \mathrm{O}
$$


In an alkaline environment, $\mathrm{Cu}_{2} \mathrm{O}_{2} \mathrm{H}^{-}$may also transform easily into $\mathrm{Cu}_{2} \mathrm{O}_{2}{ }^{2-}$, when $\mathrm{OH}^{-}$ accepts a proton.

The cuprous oxide, under the influence of hydroxyl anions, may transform into the water-soluble $\mathrm{Cu}_{2} \mathrm{O}_{2}{ }^{2-}(4)$ :

$$
\mathrm{Cu}_{2} \mathrm{O}+2 \mathrm{OH}^{-} \rightarrow \mathrm{Cu}_{2} \mathrm{O}_{2}^{2-}+\mathrm{H}_{2} \mathrm{O}
$$

Furthermore, the formed $\mathrm{Cu}_{2} \mathrm{O}_{2}{ }^{2-}$, anions are metastable and disproportionate into solid, metallic $\mathrm{Cu}$ and water-soluble $\mathrm{CuO}_{2}{ }^{2-}$, which can be also considered as $\left[\mathrm{Cu}(\mathrm{OH})_{4}\right]^{2-}(5)$ :

$$
\mathrm{Cu}_{2} \mathrm{O}_{2}^{2-} \rightarrow \mathrm{CuO}_{2}^{2-}+\mathrm{Cu}
$$

Thus, the re-deposited copper may undergo the entire cycle of reactions again, starting from Reaction (1). According to Ambrose et al., and their voltammetric study of $\mathrm{Cu}$ in $\mathrm{KOH}$, a water-soluble $\mathrm{Cu}(\mathrm{I})$ species may also be formed directly from $\mathrm{Cu}$, due to the formation of a coordination anion (6) [40]:

$$
\mathrm{Cu}+2 \mathrm{OH}^{-} \rightarrow \mathrm{Cu}(\mathrm{OH})_{2}^{-}+\overline{\mathrm{e}} \quad \mathrm{Ep}=-550 \mathrm{mV} \text { vs. } \mathrm{Hg} \mid \mathrm{HgO}
$$

However, according to Reference [40], $\mathrm{Cu}_{2} \mathrm{O}$ may also be electrochemically formed by the following Reaction (7):

$$
2 \mathrm{Cu}+2 \mathrm{OH}^{-} \rightarrow \mathrm{Cu}_{2} \mathrm{O}+\mathrm{H}_{2} \mathrm{O}+2 \overline{\mathrm{e}} \quad \mathrm{Ep}=-400 \mathrm{mV} \text { vs. } \mathrm{Hg} \mid \mathrm{HgO}
$$

The mechanism becomes more complex when the formation of $\mathrm{Cu}$ (II) from metallic $\mathrm{Cu}$ and $\mathrm{Cu}$ (I) is considered. Copper may oxidize directly to the soluble species like the coordination anion (8) [40]:

$$
\mathrm{Cu}+4 \mathrm{OH}^{-} \rightarrow \mathrm{Cu}(\mathrm{OH})_{4}^{2-}+2 \overline{\mathrm{e}} \quad \mathrm{Ep}=-100 \mathrm{mV} \text { vs. } \mathrm{Hg} \mid \mathrm{HgO}
$$

However, the already-grown cuprous oxide, $\mathrm{Cu}_{2} \mathrm{O}$, may undergo further oxidation to the abovementioned soluble species (Equations (4) and (5)), or may form insoluble cupric hydroxide:

$$
\mathrm{Cu}_{2} \mathrm{O}+2 \mathrm{OH}^{-}+\mathrm{H}_{2} \mathrm{O} \rightarrow 2 \mathrm{Cu}(\mathrm{OH})_{2}+2 \overline{\mathrm{e}} \quad \mathrm{Ep}=-100 \mathrm{mV} \text { vs. } \mathrm{Hg} \mid \mathrm{HgO}
$$

Nevertheless, this $\mathrm{Cu}(\mathrm{OH})_{2}$ deposit may form a soluble species like $\left[\mathrm{Cu}(\mathrm{OH})_{4}\right]^{2-}$ in an alkaline environment [40]. According to the fundamental work by Ambrose et al. [40], at greater potentials $\mathrm{Cu}(\mathrm{II})$ may be directly formed by copper oxidation, according to the following reactions (10) and (11):

$$
\begin{gathered}
\mathrm{Cu}+2 \mathrm{OH}^{-} \rightarrow \mathrm{Cu}(\mathrm{OH})_{2}+2 \overline{\mathrm{e}} \quad \mathrm{Ep}=0 \mathrm{mV} \text { vs. } \mathrm{Hg} \mid \mathrm{HgO} \\
\mathrm{Cu}+2 \mathrm{OH}^{-} \rightarrow \mathrm{CuO}+\mathrm{H}_{2} \mathrm{O}+2 \overline{\mathrm{e}} \quad \mathrm{Ep}=0 \mathrm{mV} \text { vs. } \mathrm{Hg} \mid \mathrm{HgO}
\end{gathered}
$$

However, $\mathrm{CuO}$ and $\mathrm{Cu}(\mathrm{OH})_{2}$ may also transform into soluble species, with copper at a greater oxidation state, namely $\mathrm{Cu}(\mathrm{III})$, when sufficiently high potentials are applied, as in reactions (12) and (13) [40]:

$$
\begin{gathered}
\mathrm{Cu}(\mathrm{OH})_{2}+2 \mathrm{OH}^{-} \rightarrow \mathrm{Cu}(\mathrm{OH})_{4}^{-}+\overline{\mathrm{e}} \quad \mathrm{Ep}=750 \mathrm{mV} \text { vs. } \mathrm{Hg} \mid \mathrm{HgO} \\
\mathrm{CuO}+\mathrm{H}_{2} \mathrm{O}+2 \mathrm{OH}^{-} \rightarrow \mathrm{Cu}(\mathrm{OH})_{4}^{-}+\overline{\mathrm{e}} \quad \mathrm{Ep}=750 \mathrm{mV} \text { vs. } \mathrm{Hg} \mid \mathrm{HgO}
\end{gathered}
$$

As can be deduced, from the abovementioned consideration, copper may form various chemical products at various oxidation states when it is electrochemically oxidized. This is in opposition to the anodization of the majority of transition metals. For example, anodizing aluminum provides only $\mathrm{Al}^{3+}$ species, namely $\mathrm{Al}_{2} \mathrm{O}_{3}$ and in some cases $\mathrm{AlO}(\mathrm{OH})$. Therefore, numerous copper anodization products, as well as the much more complex mechanism of growth, provide new areas to explore. 


\section{Strategies of Copper Anodization}

The passivation of copper, due to the abovementioned complexity, triggers numerous topics and needs for fundamental research. The easiest way to passivate electrochemically metal, that has not yet been explored in terms of anodization, is the application of a potentiostat with a three-electrode system, with which potentiostatic experiments in the passivity field are conducted according to Pourbaix diagram. Stepniowski et al. reported such a study on $\mathrm{Cu}$ passivation in $1 \mathrm{M}$ aqueous solution of $\mathrm{KOH}$ [41]. The voltammetric study showed without any doubt two distinct oxidation peaks, at ca. -450 and $-150 \mathrm{mV}$ vs. $\mathrm{Ag} \mid \mathrm{AgCl}$, responsible for metallic copper oxidation to $\mathrm{Cu}^{+}$and $\mathrm{Cu}^{2+}$, respectively. Moreover, the morphology of the obtained oxides strongly depends on the applied potential: for low potentials, micron-sized cubes were formed, mainly made of cuprous oxide, while at -200 and $-100 \mathrm{mV}$ vs. $\mathrm{Ag} \mid \mathrm{AgCl}$, nanowires were grown that were composed of a mixture of cuprous and cupric oxide (Figure 2). Nevertheless, a photoluminescence study revealed the presence of $\mathrm{CuO}$ on the surfaces of all of the samples, shedding some light on the growth mechanism. This suggests, that oxidation first occurs from $\mathrm{Cu}^{\circ}$ to $\mathrm{Cu}^{+}$and then, at the surface, $\mathrm{Cu}^{+}$oxidizes to $\mathrm{Cu}^{2+}$. This is in line with the above-described considerations of anodic oxides' growth on copper [40]. It is noteworthy that the formed nanowires grow gathered in bundles. For example, those obtained at $-200 \mathrm{mV}$ (Figure 2C) grew in bundles $72 \pm 14 \mathrm{~nm}$ thick, while individual nanowires were $24 \pm 5 \mathrm{~nm}$ thick. Those formed at $-100 \mathrm{mV}$ were gathered into bundles $90 \pm 23 \mathrm{~nm}$ thick, while the individual nanowires were $19 \pm 7 \mathrm{~nm}$ thick [41]. According to Allam and Grimes, the morphology of the grown oxide can be diverse, but it can be controlled by the operating conditions, including various additives to the electrolyte [42]. They applied a two-electrode system, using $\mathrm{KOH}$ with various salts as additives, in order to check the influence of the additives on the morphology of the formed oxide. It was found that nanoneedles formed in a pure aqueous solution of $\mathrm{KOH}(\mathrm{pH}=11)$, while an addition of halogen salts such as $\mathrm{NH}_{4} \mathrm{~F}$ and $\mathrm{NH}_{4} \mathrm{Cl}$ allowed the formation of micrometric crystals rather than nanostructures (Figure 3).

Furthermore, anodizing in ethylene glycol containing $\mathrm{KOH}$ and $\mathrm{NH}_{4} \mathrm{~F}$ also did not allow the achievement of nanostructures, like those anodized in an aqueous electrolyte. Leaf-like structures were obtained instead. Table 1 summarizes exemplary anodizing recipes in $\mathrm{KOH}$-based electrolytes. 
Table 1. Gathered experimental conditions for nanostructures formed via copper anodization in $\mathrm{KOH}$-based solutions.

\begin{tabular}{|c|c|c|c|c|}
\hline $\begin{array}{l}\text { Chemical Composition } \\
\text { of the Electrolyte }\end{array}$ & Experimental Conditions & $\begin{array}{l}\text { Morphology and Chemical } \\
\text { Composition of the Oxide }\end{array}$ & Remarks & Reference \\
\hline $\begin{array}{c}0.25 \mathrm{M} \\
0.5 \mathrm{M} \\
1.0 \mathrm{M} \\
\mathrm{K}_{2} \mathrm{C}_{2} \mathrm{O}_{4} \text { aq. }\end{array}$ & $\begin{array}{c}\text { Cyclic voltammetry: } \\
50 \mathrm{mV} / \mathrm{s} \\
\text { Range: } \\
-1.0 \text { to } 0.8 \mathrm{~V} \\
\text { RT }^{1}\end{array}$ & $\begin{array}{l}\mathrm{CuO} / \mathrm{CuO}_{x} \\
\text { Microporous structure }\end{array}$ & $\begin{array}{l}\text { Anodized surface was used as an electrochemical sensor of } \\
\text { glucose; glucose was determined at concentrations as low as } 4 \\
\text { mM in human blood serum using anodized copper }\end{array}$ & Satheesh Babu 2010 [43] \\
\hline Aqueous $\mathrm{KOH}$ & $\begin{array}{c}4-6 \mathrm{~V} \\
\mathrm{RT}\end{array}$ & Nanoneedles & No nanostructures were formed in aqueous $\mathrm{KOH}$ at $\mathrm{pH}<10$ & Allam 2011 [42] \\
\hline Aqueous $\mathrm{KOH}$ & $10 \mathrm{~V}, \mathrm{pH}=11,11.5,12$ & Nanorods & $\begin{array}{l}\text { At a pH below 10, Cu was dissolved; light blue precipitate was } \\
\text { formed on the samples; surface nanostructuring enhanced the } \\
\text { photoelectrochemical response }\end{array}$ & Shooshtari 2016 [44] \\
\hline $2 \mathrm{M} \mathrm{KOH}$ & $1.5 \mathrm{~mA} / \mathrm{cm}^{2}$, varied duration & $\mathrm{Cu}(\mathrm{OH})_{2}$ nanoneedles & $\begin{array}{l}\text { Cu mesh was anodized in order to change the contact angle (CA); } \\
\text { CA was pH-responsive: the lower the } \mathrm{pH} \text {, the greater the CA, up } \\
\text { to } 153^{\circ}\end{array}$ & Cheng 2012 [45] \\
\hline $0.5-4.0 \mathrm{M} \mathrm{KOH}$ & $\begin{array}{c}0.5-4.0 \mathrm{~mA} / \mathrm{cm}^{2}, 5-25^{\circ} \mathrm{C}, 25 \\
\min \end{array}$ & $\begin{array}{l}\text { CuO nanoneedles } \\
170 \pm 40 \mathrm{~nm} \text { in diameter } \\
7-10 \mu \mathrm{m} \text { long }\end{array}$ & $\begin{array}{l}\text { Fluoroalkyl-silane (FAS-17) was chemically bonded to } \mathrm{CuO} \\
\text { nanoneedles, increasing the contact angle up to } 169^{\circ}\end{array}$ & Xiao 2015 [46] \\
\hline $2,2.5,3,3.5 \mathrm{M} \mathrm{KOH}$ & $1.5 \mathrm{~mA} / \mathrm{cm}^{2}, 2,15,28^{\circ} \mathrm{C}$ & $\begin{array}{l}\mathrm{Cu}(\mathrm{OH})_{2} \text { and } \mathrm{CuO} \text { nanoneedles } \\
\quad 500-550 \mathrm{~nm} \text { in diameter }\end{array}$ & $\begin{array}{l}\mathrm{Cu}(\mathrm{OH})_{2} \text { were turned into } \mathrm{CuO} \text { nanoneedles using heat } \\
\text { treatment }\left(150^{\circ} \mathrm{C} \text { at } 3 \mathrm{~h}+200^{\circ} \mathrm{C} \text { at } 3 \mathrm{~h}\right) ; \text { in } 3 \mathrm{M} \mathrm{KOH} \text { at } 28^{\circ} \mathrm{C} \\
\text { nanotubes were formed }(80-500 \mathrm{~nm} \text { diameter, } 10 \mu \mathrm{m} \text { length })\end{array}$ & Wu 2005 [47] \\
\hline $1 \mathrm{M} \mathrm{KOH}$ & $\begin{array}{l}-0.4,-0.3,-0.2,-0.1 \mathrm{~V} \text { vs. } \\
\quad \mathrm{Ag} \mid \mathrm{AgCl}, \mathrm{RT}, 1 \mathrm{~h}\end{array}$ & $\begin{array}{l}\text { Morphology depends on the } \\
\text { potential; cubes and nanowires }\end{array}$ & $\begin{array}{l}\text { Formed nanowires were mixtures of } \mathrm{Cu}_{2} \mathrm{O} \text { and } \mathrm{CuO} \text {; nanowires } \\
\text { were obtained for }-0.2(24 \mathrm{~nm} \text { in diameter) and }-0.1 \mathrm{~V}(19 \mathrm{~nm} \text { in } \\
\text { diameter), while for }-0.4 \text { and }-0.3 \mathrm{~V} \text { micro-cubes were formed }\end{array}$ & Stepniowski 2017 [41] \\
\hline $\begin{array}{l}0.15 \mathrm{M} \mathrm{KOH}+0.1 \mathrm{M} \\
\mathrm{NH}_{4} \mathrm{Cl}\end{array}$ & $6 \mathrm{~V}, 300 \mathrm{~s}, \mathrm{RT}$ & Cubes and dendrites & - & Allam 2011 [42] \\
\hline $\begin{array}{c}0.15 \mathrm{M} \mathrm{KOH}+0.1 \mathrm{M} \\
\mathrm{NH}_{4} \mathrm{~F}\end{array}$ & $6 \mathrm{~V}, 300 \mathrm{~s}, \mathrm{RT}$ & $\begin{array}{c}\mathrm{Cu}_{2} \mathrm{O} \\
\text { Micro-balls made of whiskers } \\
\text { forming nanopores }\end{array}$ & $\begin{array}{l}{ }^{3} \text { XPS and }{ }^{4} \text { GAXRD proved that the structures were made } \\
\text { of } \mathrm{Cu}_{2} \mathrm{O}\end{array}$ & Allam 2011 [42] \\
\hline $\begin{array}{c}0.15 \mathrm{M} \mathrm{KOH}+0.1 \mathrm{M} \\
\mathrm{NH}_{4} \mathrm{~F}+3 \% \mathrm{H}_{2} \mathrm{O} \text { in EG }\end{array}$ & $30 \mathrm{~V}, 300 \mathrm{~s}, \mathrm{RT}$ & $\begin{array}{l}\text { 160-nm thick leaf-like } \\
\text { architectures }\end{array}$ & $\begin{array}{l}\text { When } \mathrm{KOH} \text { concentration was increased to } 0.2 \mathrm{M} \text {, the leaf-like } \\
\text { structures were ca. } 500 \mathrm{~nm} \text { thick; at voltages below } 30 \mathrm{~V} \text {, no } \\
\text { structured film was formed }\end{array}$ & Allam 2011 [42] \\
\hline $\begin{array}{l}0.75 \mathrm{wt} \% \mathrm{KOH}+3 \mathrm{wt} \% \\
\mathrm{H}_{2} \mathrm{O}+0.20-0.35 \mathrm{wt} \% \mathrm{NaF} \\
\quad \text { in EG }\end{array}$ & $10-30 \mathrm{~V}, 10 \mathrm{~min}$ & $\mathrm{Cu}_{2} \mathrm{O}$ film & $\begin{array}{l}\mathrm{Cu}_{2} \mathrm{O} \text { film was formed by anodization; further annealing } \\
\left(250-450{ }^{\circ} \mathrm{C}, 60 \mathrm{~min}\right) \text { allowed the growth of } \mathrm{CuO} \text { nanowires, } \\
\text { improving the photoelectrochemical performance }\end{array}$ & Wang 2013 [48] \\
\hline $\begin{array}{l}0.1-0.5 \mathrm{M} \mathrm{KOH}+0-0.1 \mathrm{wt} \\
\% \mathrm{NH}_{4} \mathrm{~F}+1 \mathrm{vol} \% \mathrm{H}_{2} \mathrm{O} \\
\text { in EG }\end{array}$ & $5-20 \mathrm{~V}, 5^{\circ} \mathrm{C}$ & $\begin{array}{l}\text { Nanoporous film } \\
(6-15 \mathrm{~nm} \text { pore diameter })\end{array}$ & $\begin{array}{l}\text { Nanoporous oxide was formed, composed of a mixture of the } \\
\text { following species: } \mathrm{Cu}_{2} \mathrm{O}, \mathrm{CuO}, \mathrm{Cu}(\mathrm{OH})_{2} \text {, and } \mathrm{CuF}_{2}\end{array}$ & Oyarzún Jerez 2017 [49] \\
\hline
\end{tabular}

${ }^{1}$ RT-room temperature; ${ }^{2}$ EG—ethylene glycol; ${ }^{3}$ XPS—X-ray photoelectron spectroscopy, ${ }^{4}$ GAXRD—glancing angle X-ray diffraction. 
Generally, anodization in aqueous $\mathrm{KOH}$ electrolytes results in the formation of nanoneedles [42,45-47], nanowires [41], and nanorods [44]. Specifically, in copper anodization, nanoneedles are as long as nanowires but their diameter decreases close to their top, while nanowires have quite a uniform diameter along their length (nanorods are like nanowires, but with a much smaller aspect ratio). A wide range of the structures' diameter has been observed; while Stepniowski et al. reported the smallest nanowire diameter equal $19 \mathrm{~nm}$ [41], Xiao et al. [46] reported the formation of nanoneedles with a diameter of $170 \mathrm{~nm}$ (up to $10 \mu \mathrm{m}$ long) and the formation of nanoneedles 500-550 nm thick was reported by $\mathrm{Wu}$ et al. [47]. Thus, this shows that the anodization of copper provides the possibility to tune the morphology of the grown oxides in a wide range, making this technique competitive in comparison to others. Numerous other techniques have limitations in morphology control, while anodization allows to one obtain high-aspect ratio one-dimensional (1D) nanostructures within a wide range of diameter.

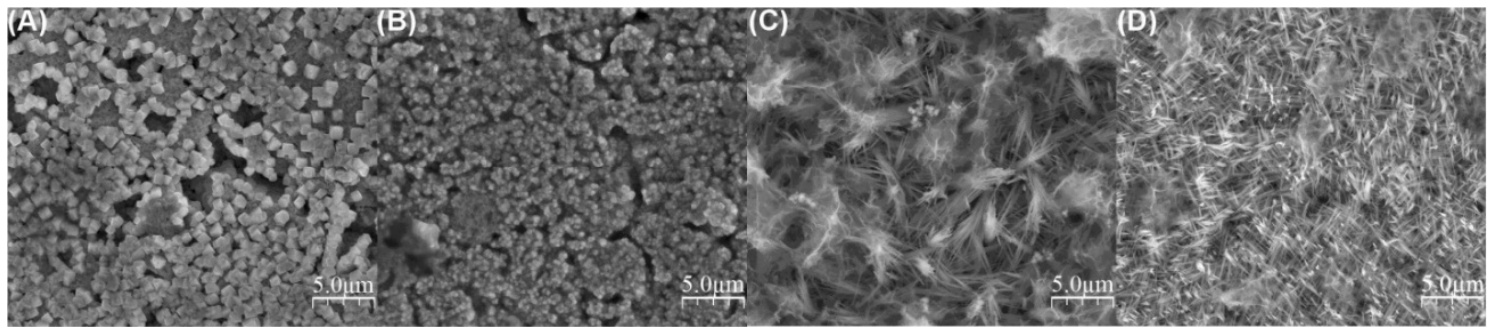

Figure 2. Top-view FE-SEM images of the surface morphology of the oxides formed via copper passivation in $1.0 \mathrm{M} \mathrm{KOH}$ at -400 (A); -300 (B); -200 (C); and $-100 \mathrm{mV}$ (D). Reproduced with permission from [41]. Elsevier, 2017.

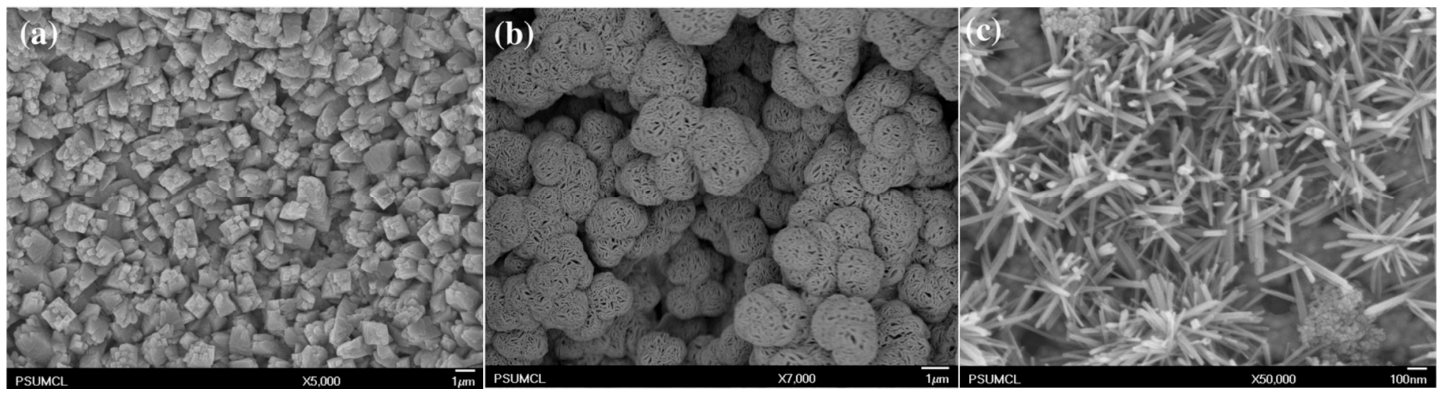

Figure 3. Top-view FE-SEM images of effects of $\mathrm{Cu}$ anodization in: (a) $0.15 \mathrm{M} \mathrm{KOH}+0.1 \mathrm{M} \mathrm{NH}_{4} \mathrm{Cl}$ at 6 $\mathrm{V}$ for $300 \mathrm{~s}$; (b) $0.2 \mathrm{M} \mathrm{KOH}+0.1 \mathrm{M} \mathrm{NH}_{4} \mathrm{~F}$ at $6 \mathrm{~V}$ for $300 \mathrm{~s}$; and (c) aqueous solution of $\mathrm{KOH}(\mathrm{pH}=11)$ at 10 V. Reproduced with permission from [42]. Elsevier, 2011.

Additives, compounds added to the electrolytes, allow the modification of the morphology, as detailed in the abovementioned publication [42]. It is worth noting that recently a manufactured nanoporous material made of $\mathrm{Cu}_{2} \mathrm{O}, \mathrm{CuO}, \mathrm{Cu}(\mathrm{OH})_{2}$, and $\mathrm{CuF}_{2}$ was obtained with a pore diameter ranging from 6 to $15 \mathrm{~nm}$ [49]. Typically, the majority of the anodic oxides formed on copper are made of nanowires, nanoneedles, or nanorods. Nanoporous morphology is typical for oxides grown on other metals. Moreover, the pores formed via copper anodization have smaller diameters than the majority obtained by aluminum anodization. However, the ordering of the pores formed on copper is much poorer, compared to highly-ordered AAO. Nevertheless, the formation of porous oxide on copper confirms the vast variety of morphologies possible to obtain by anodization.

It is also worth noting that, analogous to aluminum anodization, and in the case of copper anodization, both potentiostatic and galvanostatic approaches are used. At a constant voltage (potentiostatic approach), the voltage resulting in the formation of anodic oxides in $\mathrm{KOH}$-based solutions ranges from 4 to $30 \mathrm{~V}$ in two-electrode systems. When the galvanostatic approach is used, the current density ranges from 0.5 to $4.0 \mathrm{~mA} / \mathrm{cm}^{2}$ (Table 1). Due to the alkaline hydrolysis, potassium 
oxalate was also successfully applied in copper anodization [43], producing a microporous mixture of $\mathrm{CuO}$ and $\mathrm{CuO}_{x}$ due to the appropriate $\mathrm{pH}$ of the applied electrolyte (compare to the Pourbaix diagram, Figure 1). Thus, this shows there is still much to explore in the anodization of copper. THe Pourbaix diagram shows numerous opportunities for copper anodization at a more ambient $\mathrm{pH}$. Carbonates and bicarbonates of alkali metals would be ideal for further fundamental research in this field.

$\mathrm{Wu}$ et al. recently reported the behavior of copper in $0.1 \mathrm{M} \mathrm{NaOH}$ during cyclic voltammetry scans. According to their findings, copper in $\mathrm{NaOH}$ oxidizes in a few stages: at low potentials, $\mathrm{Cu}_{2} \mathrm{O}$ is first formed, then $\mathrm{Cu}_{2} \mathrm{O}$ at the surface is oxidized to $\mathrm{CuO}$, and finally, $\mathrm{Cu}(\mathrm{OH})_{2}$ forms the outer layer of the oxide structures [50]. These findings are analogous to the recent results for $\mathrm{Cu}$ oxidation in $1 \mathrm{M} \mathrm{KOH} \mathrm{[41]} \mathrm{and} \mathrm{they} \mathrm{are} \mathrm{also} \mathrm{in} \mathrm{line} \mathrm{with} \mathrm{the} \mathrm{Pourbaix} \mathrm{diagram,} \mathrm{where} \mathrm{at} \mathrm{lower} \mathrm{potentials}$ copper oxidized to $\mathrm{Cu}_{2} \mathrm{O}$ and then, at greater potentials, oxidized to $\mathrm{CuO}$ (Figure 1). Anodization in $\mathrm{NaOH}$-based solutions also allows the formation of various nanostructures. The most desired nanostructures are nanoneedles and nanowires, due to their high surface area, like those formed in $1 \mathrm{M}$ $\mathrm{NaOH}$ (Figure 4). Table 2 summarizes the recipes for copper anodization in $\mathrm{NaOH}$-based solutions.

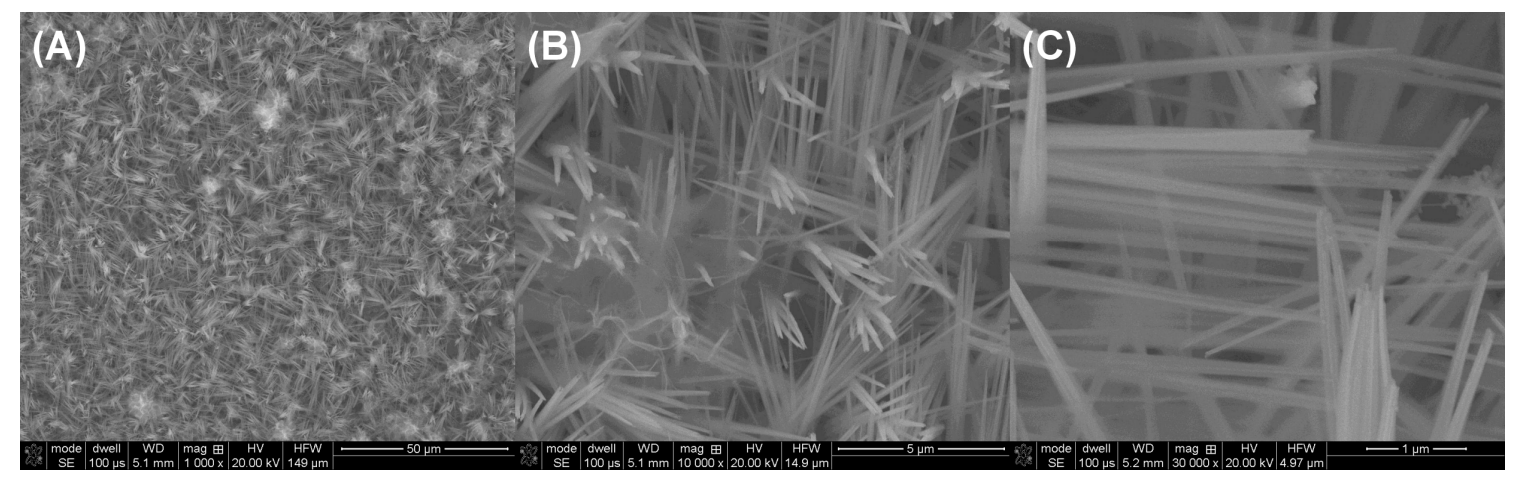

Figure 4. FE-SEM images of nanostructures grown on copper in $1.0 \mathrm{M} \mathrm{NaOH}$ at $-200 \mathrm{mV}$ vs. $\mathrm{Ag} \mid \mathrm{AgCl}$ for $10 \mathrm{~min}$ at room temperature (RT). Images taken at different magnifications (A-C). Unpublished research by Stępniowski et al. 
Table 2. Gathered experimental conditions for nanostructures formed via copper anodization in NaOH-based solutions.

\begin{tabular}{|c|c|c|c|c|}
\hline $\begin{array}{l}\text { Chemical Composition } \\
\text { of the Electrolyte }\end{array}$ & Experimental Conditions & $\begin{array}{l}\text { Morphology and Chemical } \\
\text { Composition of the Oxide }\end{array}$ & Remarks & Reference \\
\hline $0.1 \mathrm{M} \mathrm{NaOH}$ & $-400 \mathrm{mV}, 1 \mathrm{~h}$ & Nanoparticles & Mechanism of oxide growth was studied & Caballero-Briones 2010 [51] \\
\hline $0.1 \mathrm{M} \mathrm{NaOH}$ & $\begin{array}{c}10 \mathrm{mV} / \mathrm{s} \text { voltammetric scan } \\
\text { from }-1.2 \text { to } 0.8 \mathrm{~V} \\
\mathrm{RT}\end{array}$ & $\begin{array}{l}\text { Cu needle was anodized and coated } \\
\text { by oxide-hydroxide film }\end{array}$ & Mechanism of $\mathrm{Cu}$ electrochemical oxidation was investigated & Wu $2013[50]$ \\
\hline $1 \mathrm{M} \mathrm{NaOH}$ & $0.06 \mathrm{~mA} / \mathrm{cm}^{2}, 5 \mathrm{~min}, 25^{\circ} \mathrm{C}$ & $\mathrm{Cu}(\mathrm{OH})_{2}$ nanowires & $\begin{array}{l}\text { Nanowires surface was modified by the chemical bonding of } \\
1 \mathrm{H}, 1 \mathrm{H}, 2 \mathrm{H}, 2 \mathrm{H} \text {-Perfluorodecyltriethoxysilane (FAS-17) in order to } \\
\text { increase the wetting contact angle to } 154^{\circ} ; \text { as-obtained } \\
\text { nanowires were made of } \mathrm{Cu}(\mathrm{OH})_{2} \text {, but further annealing } \\
\text { enabled the transofrmation of the hydroxide into } \mathrm{CuO}\end{array}$ & Jiang 2015 [52] \\
\hline $1 \mathrm{M} \mathrm{NaOH}$ & $\begin{array}{c}\text { Cyclic voltammetry from } \\
-1.6 \mathrm{~V} \text { to } 0.4 \mathrm{~V} \\
\text { RT }\end{array}$ & $\begin{array}{l}\mathrm{CuO} \text { dendrite crystals grown on } \\
\qquad \mathrm{Cu}_{2} \mathrm{O} \text { nanoparticles }\end{array}$ & Cyclic voltammetric study of $\mathrm{Cu}$ in alkaline solution & Wan 2013 [53] \\
\hline $3 \mathrm{M} \mathrm{NaOH}$ & $1.5,3.0,5.0 \mathrm{~mA} / \mathrm{cm}^{2}, 30 \mathrm{~min}$ & $\underset{\text { nanowires }}{\mathrm{Cu}_{2} \mathrm{O}, \mathrm{Cu}_{2} \mathrm{O} / \mathrm{Cu}(\mathrm{OH})_{2}, \mathrm{Cu}(\mathrm{OH})_{2}}$ & $\begin{array}{l}\text { Cu was electrodeposited on ITO (Indium Tin Oxide) and } \\
\text { subsequently anodized; obtained nanostructures enhanced } \\
\text { photocatalytic water splitting; the best results were achieved for } \\
\text { nanowires made of both } \mathrm{Cu}_{2} \mathrm{O} \text { and } \mathrm{CuO}\end{array}$ & Zhang 2012 [54] \\
\hline $0.15 \mathrm{M} \mathrm{NaOH}$ & $\begin{array}{c}\mathrm{pH}=12.8-13.0 \\
-430 \mathrm{mV}\end{array}$ & $\begin{array}{c}\mathrm{Cu}_{2} \mathrm{O} \\
\text { nanoparticles }\end{array}$ & $\mathrm{Cu}_{2} \mathrm{O}$ behaved like a p-type semiconductor & Caballero-Briones 2009 [55] \\
\hline $\begin{array}{c}1 \mathrm{M} \mathrm{NaOH}+2.5 \mathrm{M} \mathrm{NaCl}+ \\
0.5 \mathrm{~g} / \mathrm{L} \mathrm{EG}\end{array}$ & $\begin{array}{l}0.5-2.5 \mathrm{~A} / \mathrm{dm}^{2}, 55-70{ }^{\circ} \mathrm{C} \\
\quad 30 \mathrm{~min}\end{array}$ & $\begin{array}{l}\text { 30-nm thick nanosheets made of } \\
\mathrm{CuO} \text { and } \mathrm{Cu}_{2} \mathrm{O}\end{array}$ & Formed nanostructures are mixtures of $\mathrm{CuO}$ and $\mathrm{Cu}_{2} \mathrm{O}$ & Shu 2017 [56] \\
\hline $\begin{array}{c}10 \mathrm{wt} \% \mathrm{NaOH}+5 \mathrm{wt} \% \\
\mathrm{NaClO}_{2}\end{array}$ & $0.75 \mathrm{~V}, 60^{\circ} \mathrm{C}, 15 \mathrm{~min}$ & $\begin{array}{l}\mathrm{CuO} \text { films with traces of } \mathrm{Cu}_{3} \mathrm{O}_{2}, \\
\text { decomposing to } \mathrm{CuO} \text { and } \mathrm{Cu}_{2} \mathrm{O}\end{array}$ & $\begin{array}{l}\text { After anodizing, samples were immersed in } \mathrm{KMnO}_{4} \\
\text { consequently, solar light absorption reached up to } 96 \%\end{array}$ & Arurault 2007 [57] \\
\hline $\begin{array}{l}0.2 \mathrm{M} \mathrm{NH}_{4} \mathrm{Cl} ; \mathrm{pH} \text { was } \\
\text { adjusted to } 8 \text { with } \mathrm{NaOH}\end{array}$ & $5 \mathrm{~mA} / \mathrm{cm}^{2}, \mathrm{RT}, 20 \mathrm{~min}$ & $\mathrm{Cu}(\mathrm{OH})_{2}$ film & $\begin{array}{l}\text { In order to transform } \mathrm{Cu}(\mathrm{OH})_{2} \text { into } \mathrm{Cu}_{2} \mathrm{O} \text {, three } \\
\text { post-treatments were applied: hydrolysis in } \mathrm{H}_{2} \mathrm{O}_{2} \text {, reduction in } \\
\mathrm{H}_{2} \text { at } 280^{\circ} \mathrm{C} \text {, redox with glucose; the } \mathrm{H}_{2} \mathrm{O}_{2} \text { post-treated sample } \\
\text { had the best efficiency in oxygen generation }\end{array}$ & Zhang 2015 [58] \\
\hline
\end{tabular}


According to Table 2, it is apparent that various approaches were tested to grow anodic oxides on $\mathrm{Cu}$ in $\mathrm{NaOH}$-based electrolytes. Here also the three-electrode approach using cyclic voltammetry $[50,53]$ or constant potential $[51,55,57]$ was applied. In a two-electrode approach, galvanostatic anodizing was applied with current densities in the range of $0.06 \mathrm{~mA} / \mathrm{cm}^{2}$ [52] up to $5 \mathrm{~mA} / \mathrm{cm}^{2}[54,58]$. The concentration of $\mathrm{NaOH}$ in the applied electrolyte was used in the range from $0.1[50,51]$ to $3.0 \mathrm{M}[54]$, but also in this case, various additives were used to grow the nanostructured oxides, namely: $\mathrm{NaCl}$ with ethylene glycol [56], $\mathrm{NaClO}_{2}$ in order to enhance oxidation [57], and $\mathrm{NH}_{4} \mathrm{Cl}$ [58]. The application of sodium hydroxide-based electrolytes allowed the achievement of oxides with various morphologies, such as nanoparticles [51,53,55], nanowires [52,54], dendrites [53], nanoneedles [50], and nanosheets [56]. Also in this case, copper anodization offered a wide range of nanoneedle diameters and a high aspect ratio, overcoming the limitations of other techniques (Table 2).

In further applications, especially in physical ones such as photovoltaics, chemical cleanness is crucial. Unfortunately, in the majority of the research, detailed chemical composition analyses, mainly $\mathrm{X}$-ray photoelectron spectroscopy (XPS), have revealed the simultaneous presence of $\mathrm{Cu}_{2} \mathrm{O}, \mathrm{CuO}$, or even $\mathrm{Cu}(\mathrm{OH})_{2}$ in the grown nanostructures [56-58]. For energy harvesting applications, such as $\mathrm{PV}$ (photovoltaics) or photocatalytic water decomposition, $\mathrm{Cu}_{2} \mathrm{O}$ is the most demanded among the copper species and its nanostructured form provides numerous surpluses thanks to its high surface area. To face the challenge of chemical composition homogeneity, Zhang et al. reported three methods of transforming $\mathrm{Cu}(\mathrm{OH})_{2}$ nanostructures into $\mathrm{Cu}_{2} \mathrm{O}$ [58]. One of them was hydrolysis with hydrogen peroxide (14):

$$
2 \mathrm{Cu}(\mathrm{OH})_{2}+2 \mathrm{H}_{2} \mathrm{O}_{2} \rightarrow \mathrm{Cu}_{2} \mathrm{O}+\mathrm{O}_{2}+3 \mathrm{H}_{2} \mathrm{O}
$$

Another involved the annealing of the anodized samples in hydrogen at $280{ }^{\circ} \mathrm{C}(15)$ :

$$
2 \mathrm{Cu}(\mathrm{OH})_{2}+2 \mathrm{H}_{2} \rightarrow \mathrm{Cu}_{2} \mathrm{O}+3 \mathrm{H}_{2} \mathrm{O}
$$

And the third involved a reaction with glucose (used in electrochemical glucose sensing) that allowed the reduction of $\mathrm{Cu}(\mathrm{OH})_{2}$ to $\mathrm{Cu}_{2} \mathrm{O}(16)$ :

$$
2 \mathrm{Cu}(\mathrm{OH})_{2}+\mathrm{CH}_{2}-(\mathrm{CHOH})_{4}-\mathrm{CHO} \rightarrow \mathrm{Cu}_{2} \mathrm{O}+\mathrm{CH}_{2}-(\mathrm{CHOH})_{4}-\mathrm{COOH}+2 \mathrm{H}_{2} \mathrm{O}
$$

The obtained cuprous oxide had improved ability in photocatalytic oxygen generation from water, although the best results (the most efficient oxygen production) were achieved with the samples treated with hydrogen peroxide. This means that the reduction of copper from $\mathrm{Cu}(\mathrm{II})$ to $\mathrm{Cu}(\mathrm{I})$ was the most efficient. Therefore, the nanostructures obtained by $\mathrm{Cu}$ anodization can be chemically reduced, forming high-surface area material made of $\mathrm{Cu}_{2} \mathrm{O}$. Such numerous options of cuprous oxide as well as cupric oxide nanostructuring allow researchers to apply these nanostructures in various devices.

\section{Properties and Applications of Anodic Nanostructures Grown on Copper}

The high surface area and chemical composition that could be tailored via anodization encouraged scientists to apply these materials in areas such as tunable contact angle surfaces, sensing, and renewable energy harvesting.

As mentioned above, the copper species formed via anodization are at various oxidation states. Also, chemical post-treatments can be applied to oxidize or reduce the formed nanostructures. Thus, they can form redox couples with various chemical compounds, providing reactions that can be electrochemically sensed. One such reaction is glucose oxidation to gluconic or glucuronic acid (see Equation (16)). However, the $\mathrm{C}-\mathrm{C}$ bonds in glucose may undergo dissociation during the electrochemical oxidation and form shorter products like formats, or even carbonates. Simultaneously, active surface $\mathrm{Cu}$ (III) species are reduced to $\mathrm{Cu}$ (II) [43]. Satheesh Babu and Ramachandran anodized $\mathrm{Cu}$ in potassium oxalate in order to obtain an electrochemical glucose sensor [43]. This allowed 
the formation of $\mathrm{CuO}$ with a developed surface area, which is desired in sensing applications. Applied potassium oxalate solution as the electrolyte allowed the incorporation of oxalates into the $\mathrm{CuO}$, in the form of $\mathrm{Cu}$ (II) oxalate. This in situ doping approach has already been intensively researched for other anodic oxides, like alumina [37]. However, it was shown in this work [43] that the in situ doping of $\mathrm{CuO}$ is also possible and beneficial for sensing applications. The electrochemical sensor made of $\mathrm{Cu}$ coated with $\mathrm{CuO}$ and copper oxalate was found to have a sensitivity as high as $1.89 \mathrm{~mA} \cdot \mathrm{mM}^{-1} \cdot \mathrm{cm}^{-2}$ with a detection limit equal to $50 \mathrm{nM}$. Additionally, the sensor was found to work in the presence of other interfering compounds like ascorbic acid and uric acid, as well as in samples of human blood serum, confirming its outstanding selectivity towards glucose.

Due to the developed surface area and diverse morphologies of the formed anodic films, the modification of the wetting of the surface can be provided by copper anodization. There are two main approaches describing the behavior of liquids on surfaces with nanostructures on the top (and mixed approaches as well): Wenzel's approach, in which the nanostructures are deeply penetrated by the liquid, and Cassie-Baxter's method, in which the liquid does not penetrate the nanostructures and air remains trapped inside them. According to Jiang et al., the nanostructures grown via copper anodization are in the Cassie-Baxter state [52]. They anodized copper in $1 \mathrm{M} \mathrm{NaOH}$ (Table 2) and obtained $\mathrm{Cu}(\mathrm{OH})_{2}$ nanowires that were hydrophilic (wetting contact angle was $4.5^{\circ}$ and $0^{\circ}$ for water and $\mathrm{CH}_{2} \mathrm{I}_{2}$, respectively). Due to the provided modification of the surface with the chemical bonding of FAS-17 ( $2 \mathrm{H}, 2 \mathrm{H}$-Perfluorodecyltriethoxysilane), the contact angle increased significantly to $154^{\circ}$ and $133^{\circ}$ for water and $\mathrm{CH}_{2} \mathrm{I}_{2}$, respectively [52]. FAS-17-modified $\mathrm{CuO}$ nanostructures were also used to research anti-corrosion applications of the as-formed hydrophobic coating. Xiao et al. reported the formation of $\mathrm{CuO}$ nanoneedles in $\mathrm{KOH}$ that were 7-10 $\mu \mathrm{m}$ long and ca. $170 \mathrm{~nm}$ in diameter (Table 1) (Figure 5A,B) [46]. Post-treatment with FAS-17 allowed the increase of the wetting water contact angle up to $169^{\circ}$, providing superhydrophobicity (Figure 5C,D). Furthermore, the limited contact between the surface and surrounding liquid environment (Cassie-Baxter state) hinders galvanic coupling with the material underneath, consequently improving the corrosion performance. After $\mathrm{Cu}$ anodization for $40 \mathrm{~min}$ in $2 \mathrm{M} \mathrm{KOH}$ at $2 \mathrm{~mA} \cdot \mathrm{cm}^{-2}$ at $15^{\circ} \mathrm{C}$, the corrosion potential increased from -254 to $-212 \mathrm{mV}$, while the corrosion current density recorded in $3.5 \% \mathrm{NaCl}$ decreased from $19.58 \mu \mathrm{A} \cdot \mathrm{cm}^{-2}$ to $9.11 \mu \mathrm{A} \cdot \mathrm{cm}^{-2}$ [46]. Further surface chemical modification by FAS-17 bonding increased the hydrophobicity and consequently increased the corrosion potential to $-124 \mathrm{mV}$ and decreased corrosion current to $0.66 \mu \mathrm{A} \cdot \mathrm{cm}^{-2}$. After one week of immersion in $3.5 \% \mathrm{NaCl}$, the corrosion performance of the anodized and chemically modified copper remained satisfactory: the corrosion current density was then $0.99 \mu \mathrm{A} \cdot \mathrm{cm}^{-2}$ and the corrosion potential was $-134 \mathrm{mV}$ (Figure 5E,F). Thus, morphologically and chemically generated hydrophobicity could hinder the charge transfer at the electrolyte-sample interface, as confirmed by electrochemical impedance spectroscopy (EIS)-derived charge transfer resistance, which was $2.47 \mathrm{k} \Omega \cdot \mathrm{cm}^{2}$ for anodized and modified samples vs. $0.25 \mathrm{k} \Omega \cdot \mathrm{cm}^{2}$ for pristine $\mathrm{Cu}$ and $0.44 \mathrm{k} \Omega \cdot \mathrm{cm}^{2}$ for the only anodized surface.

Another application, using the superhydrophobic effect admitted to the morphology of anodic oxides grown on copper, employs a $\mathrm{pH}$-responsive water permeation mesh [45]. $\mathrm{Cu}(\mathrm{OH})_{2}$ nanoneedles formed in $\mathrm{KOH}$ (see Table 1 and Figure 6A-C) were coated with gold and then thiols, $\mathrm{HS}\left(\mathrm{CH}_{2}\right)_{9} \mathrm{CH}_{3}$ and $\mathrm{HS}\left(\mathrm{CH}_{2}\right)_{10} \mathrm{COOH}$, were chemically bonded to the surface. At a low $\mathrm{pH}$, such a nanostructured mesh had a contact angle equal $153^{\circ}$, which did not allow water to pass through the mesh (Figure 6D). However, increasing $\mathrm{pH}$ to 12 significantly decreased the contact angle $\left(\mathrm{ca} .8^{\circ}\right.$ ) and consequently the mesh was permeable to water [43]. What is even more interesting, the $\mathrm{pH}$-response time was about $3 \mathrm{~s}$. Moreover, this system was reversible and switching the $\mathrm{pH}$ allowed one to switch contact angle and, consequently, the permeability. It is also important to note that the starting material had a complex geometry in the micro scale (mesh) and it was successfully anodized. Therefore, this paper shows that samples with sophisticated morphology can be anodized, providing cuprous and cupric oxide nanostructures on the surface. Typically, when $\mathrm{Al}$ or Ti are anodized, the starting material samples are plates or rods. Very often, due to the complex geometry of the metallic substrate, anodization 
is impossible because the anodic dissolution of metals occurs at the exposed edges of the sample. Reporting the anodization of $\mathrm{Cu}$ mesh enables numerous opportunities in other applications, where already the starting material must have complex geometry, but formation of surface nanostructures would be beneficial and in-demand.
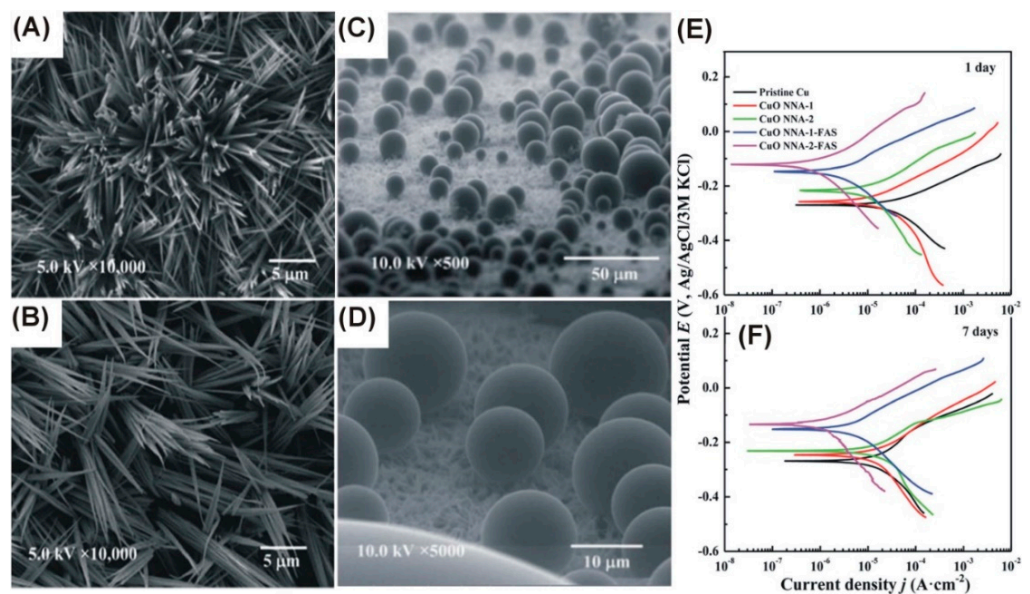

Figure 5. Top-view FE-SEM images of $\mathrm{CuO}$ nanoneedles formed in $2 \mathrm{M} \mathrm{KOH}$ at $15{ }^{\circ} \mathrm{C}, 2 \mathrm{~mA} \cdot \mathrm{cm}^{-2}$ for 25 (A) and $40 \mathrm{~min}(\mathbf{B})$; behavior of $3.5 \% \mathrm{NaCl}$ solution on their surface after the chemical bonding of FAS-17 (C,D) and their corrosion performance after 1 (E) and seven days of immersion in 3.5\% $\mathrm{NaCl}(\mathbf{F})$. CuO NAA-1 and CuO NAA-2 indicate anodization for 25 and 40 min, while FAS denotes the subsequent modification with FAS-17. Reproduced with permission from [46]. Royal Society of Chemistry, 2015.

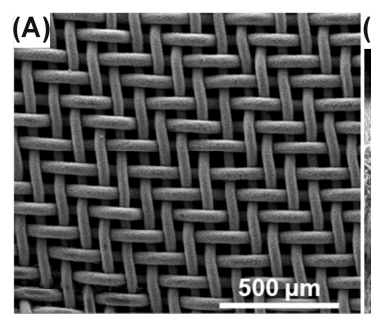

(D)

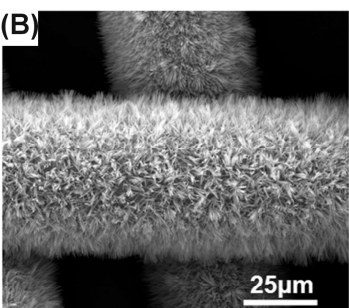

$25 \mu \mathrm{m}$

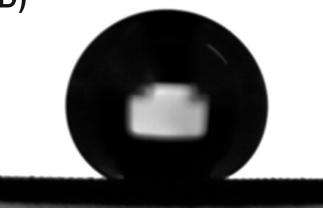

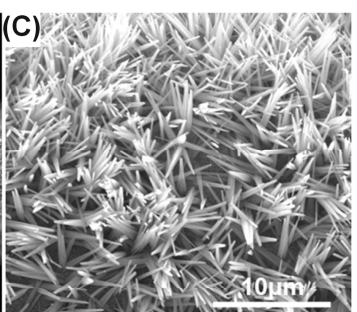

(E)

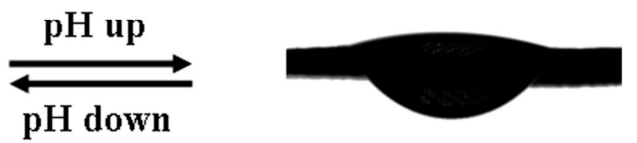

Figure 6. SEM images of $\mathrm{Cu}$ mesh subjected to anodization in $2 \mathrm{M} \mathrm{KOH}$ at $1.5 \mathrm{~mA} \cdot \mathrm{cm}^{-2}(\mathbf{A}-\mathbf{C})$ and water permeation performance after anodization, Au sputtering, and functionalization with thiols (E,F); water droplet size was $4 \mu \mathrm{L}(\mathbf{D}, \mathbf{E})$ and $\mathrm{pH}$ was 2 (D) and 12 (E). Reproduced with permission from [45]. American Chemical Society, 2012.

One of the applications in which cupric oxide nanostructures formed via anodization may bring significant input is renewable energy harvesting [59]. $\mathrm{Cu}_{2} \mathrm{O}$ (a p-type semiconductor) coupled with $\mathrm{ZnO}$ (an n-type semiconductor) can be used as an efficient hetero-junction photovoltaic cell. However, so far only around a $6 \%$ power conversion efficiency (PCE) of $\mathrm{Cu}_{2} \mathrm{O}$-based photovoltaic cells has been reported, versus 23\% of the theoretical PCE value [59]. Numerous nanostructuring approaches, including the above-discussed anodization, may bring progress in the PCE. Due to the electronic structure of $\mathrm{Cu}_{2} \mathrm{O}$ and $\mathrm{CuO}$, nanostructures obtained by copper anodization will find applications in renewable fuel generation, namely in photoelectrochemical (PEC) water splitting. The semiconducting 
photocathode has a suitable band gap for water splitting reactions, which is within the band gap of $\mathrm{Cu}_{2} \mathrm{O}$ and $\mathrm{CuO}$.

It is important to note that the band gap of $\mathrm{CuO}$ is smaller than that of $\mathrm{Cu}_{2} \mathrm{O}$; moreover, both the valence and conduction bands of $\mathrm{CuO}$ are lower than those of $\mathrm{Cu}_{2} \mathrm{O}$. Briefly, after the excitation of the photocathode made of $\mathrm{Cu}_{2} \mathrm{O}-\mathrm{CuO}$ film, when the excited electron will exceed the band gap of $\mathrm{Cu}_{2} \mathrm{O}$, it can reduce its energy down to the conduction band of $\mathrm{CuO}$ and by further reduction cause the decomposition of water, generating gaseous hydrogen and oxygen. Nevertheless, one should be aware that corrosive reactions, like $\mathrm{Cu}_{2} \mathrm{O}$ or $\mathrm{CuO}$ reduction, may occur as well, affecting the performance of the photocatalyst over time. Zhang et al. reported an extensive study on copper anodization for photoelectrochemical water splitting [56]. They investigated a few strategies of copper anodization, employing various current densities and post-treatments such as post-annealing, causing calcinations and improving the crystallinity of the formed nanoneedles (Table 2). The reported research confirmed that the mixed oxide nanoneedles, consisting of a $\mathrm{Cu}_{2} \mathrm{O}-\mathrm{CuO}$ system, have the best performance towards PEC water splitting. The greatest photocurrents were recorded for $\mathrm{Cu} / \mathrm{Cu}_{2} \mathrm{O} / \mathrm{CuO}$ and $\mathrm{Cu} / \mathrm{Cu}_{2} \mathrm{O} / \mathrm{Cu}(\mathrm{OH})_{2}$, namely -1.54 and $-1.28 \mathrm{~mA} / \mathrm{cm}^{2}$, respectively, at no external voltage $(0 \mathrm{vs}$. NHE - Normal Hydrogen Electrode). Nevertheless, due to the mentioned corrosion of cupric and cuprous oxide, their stability dropped over time. $\mathrm{Cu} / \mathrm{Cu}_{2} \mathrm{O} / \mathrm{CuO}$ and $\mathrm{Cu} / \mathrm{Cu}_{2} \mathrm{O} / \mathrm{Cu}(\mathrm{OH})_{2}$ preserved after $20 \mathrm{~min}$ represented $74.4 \%$ and $85.8 \%$ of their performance, respectively. Pure $\mathrm{Cu}_{2} \mathrm{O}$ film, after $20 \mathrm{~min}$ of performance, had only $30.1 \%$ of its primal conversion efficiency (simultaneously harvesting a much lower current density: $-0.65 \mathrm{~mA} / \mathrm{cm}^{2}$ ).

Photocatalytic oxygen generation is another method of renewable energy harvesting, enabling the storage of energy. In order to generate oxygen from water, photo-generated holes have to recombine on the surface of the catalyst, according to Equation (17) [58]:

$$
2 \mathrm{H}_{2} \mathrm{O}+4 \mathrm{~h}^{+} \rightarrow \mathrm{O}_{2}+4 \mathrm{H}^{+}
$$

This reaction lays in the band gap of $\mathrm{Cu}_{2} \mathrm{O}$, thus nanostructures formed by $\mathrm{Cu}$ anodization are also suitable for this application. However, in contrast to PEC water splitting, in this case the presence of $\mathrm{CuO}$ would affect the yield of the reaction. Thus, the authors [58] worked out three various approaches to reduce $\mathrm{Cu}(\mathrm{II})$ to $\mathrm{Cu}(\mathrm{I})$, mentioned in the previous section (Equations (14)-(16)). According to the authors, the oxygen generation reaction occured efficiently due to the contact of metallic $\mathrm{Cu}$ with $\mathrm{Cu}_{2} \mathrm{O}$, as it allowed the rapid acceptance of electrons generated by metal, with a simultaneous rapid conversion of holes on the catalysts' surface. Thus, the formation of charge imbalance was hindered due to this junction. Among three post-treatment methods, hydrolysis with hydrogen peroxide obtained the greatest oxygen production yield, providing $233.27 \mu \mathrm{mol}$ from $1 \mathrm{mg}$ of catalyst in $8 \mathrm{~h}$ of its performance, while methods obtained results below $185 \mu$ mol of $\mathrm{O}_{2}$ [58].

On the other hand, the post-treatment of the grown anodic oxides with $\mathrm{KMnO}_{4}$ was reported by Arurault et al. [57]. This enabled the oxidization of the grown anodic film to $\mathrm{CuO}$ and $\mathrm{Cu}_{3} \mathrm{O}_{2}$. The highly-developed surface area combined with the chemical composition increased solar light absorption. Thus, it was demonstrated that anodic oxides grown on copper are suitable for solar cell applications.

A brief review of anodic oxides grown on copper with their applications is presented in Table 3 . It leads to the conclusion that the major applications of anodic oxides grown on copper result from their chemical composition and nanostructured morphology. However, most applications are reported for anodic oxides in the form of nanoneedles. This form of nanostructure provides high-surface area for photocatalytic reactions high wetting contact angle (after functionalization), and high sensitivity. 
Table 3. Gathered information about applications of nanostructures formed via copper anodization.

\begin{tabular}{|c|c|c|c|}
\hline Application & Role of the Anodically Grown Nanostructures & Remarks & Reference \\
\hline Glucose sensor & $\begin{array}{c}\text { High surface area } \\
\mathrm{Cu}(\mathrm{III}) \text { active sites were reducted to } \mathrm{Cu}(\mathrm{II}) \\
\text { by glucose }\end{array}$ & $\begin{array}{c}\text { Glucose was determined at concentrations as low as } 4 \mathrm{mM} \text { in human } \\
\text { blood serum }\end{array}$ & [43] \\
\hline $\mathrm{pH}-$ responsive water permeation mesh & High surface area & $\begin{array}{c}\text { Wetting contact angle was } \mathrm{pH} \text {-switchable and for a lower } \mathrm{pH} \text { it } \\
\text { reached up to } 153^{\circ}\end{array}$ & [45] \\
\hline $\begin{array}{l}\text { High contact angle surface for corrosion } \\
\text { protection }\end{array}$ & Highly-developed nanostructured surface area & $\begin{array}{l}\text { Fluoroalkyl-silane (FAS-17) was chemically bonded to } \mathrm{CuO} \\
\text { nanoneedles, increasing the contact angle up to } 169^{\circ} \text {; the corrosion } \\
\text { performance was significantly improved }\end{array}$ & [46] \\
\hline Photoelectrochemical chemical water splitting & $\begin{array}{l}\text { Highly-developed surface area and chemical } \\
\text { composition }\left(\mathrm{CuO}-\mathrm{Cu}_{2} \mathrm{O}\right)\end{array}$ & $\begin{array}{l}\text { Nanostructures enhanced photocatalytic water splitting; the best } \\
\text { results were achieved for nanowires made of both } \mathrm{Cu}_{2} \mathrm{O} \text { and } \mathrm{CuO}\end{array}$ & [54] \\
\hline Photochemical oxygen generation & $\begin{array}{l}\text { High surface area and chemical composition } \\
\qquad\left(\mathrm{Cu}_{2} \mathrm{O}\right)\end{array}$ & Post-treatment of obtained nanostructures was conducted & [58] \\
\hline Solar light absorption & Chemical composition $\left(\mathrm{CuO}\right.$ with $\left.\mathrm{Cu}_{3} \mathrm{O}_{2}\right)$ & Post-treatment in $\mathrm{KMnO}_{4}$ was conducted & [57] \\
\hline
\end{tabular}




\section{Anodization versus Other Nanostructured Copper Oxide Fabrication Methods}

According to the abovementioned applications, 1D cuprous and cupric oxide nanostructures may bring valuable contributions to many fields. Thus, a variety of the $\mathrm{Cu}_{2} \mathrm{O}$ and $\mathrm{CuO}$ synthesis techniques are being developed by researchers. The literature study shows that the self-organized anodization of copper may be attractive for few reasons (Table 4):

- It employs inexpensive equipment;

- It is time-efficient;

- It is an easy technique to scale-up, as it employs self-organization (no template required);

- It does not require numerous steps, only electropolishing and one step of the electrochemical oxidation;

- It allows for the control of geometry and provides 1D nanostructures with a high aspect ratio.

On the other hand, there are numerous competitive chemical techniques, like precipitation, sol-gel, or hydrothermal synthesis, but 1D nanostructures obtained with those methods have much smaller aspect ratios. Moreover, the chemical syntheses are multistep processes. Additionally, some of the steps take tens of hours to complete. Template-assisted techniques that also employ atomic layer deposition (ALD) may provide high aspect ratio 1D nanostructures made of cuprous and cupric oxides; however, these methods are also multistep (the formation of template also must be taken into account) and employ expensive tools (ALD).

Therefore, the self-organized anodization of copper, resulting in the formation of 1D nanostructures, may nowadays attract much more attention due to the offered solutions and potential applications of the nanostructures.

Table 4. Drawbacks of currently applied copper oxides nanostructuring methods vs. solutions offered by anodizing.

\begin{tabular}{|c|c|c|c|}
\hline Fabrication Method & Drawbacks of the Method & Solution offered by Anodizing & Reference \\
\hline Hydrothermal synthesis & $\begin{array}{c}\text { Small aspect ratio of } \\
\text { one-dimensioanl (1D) } \\
\text { nanostructures; requires a few } \\
\text { steps of synthesis }\end{array}$ & $\begin{array}{l}\text { High aspect ratio of 1D nanostructures can be } \\
\text { easily achieved by lengthening the time of } \\
\text { anodization; facile, easy-to-scale-up two-step } \\
\text { synthesis (electropolishing + anodizing) }\end{array}$ & {$[35,36]$} \\
\hline Atomic layer deposition & $\begin{array}{l}\text { Requires templates and expensive } \\
\text { equipment to grow 1D } \\
\text { nanostructures }\end{array}$ & $\begin{array}{l}\text { Method based on easy to scale-up } \\
\text { self-organization; inexpensive, } \\
\text { electrochemical method }\end{array}$ & {$[35,36]$} \\
\hline $\begin{array}{l}\text { Solution-based chemical } \\
\text { precipitation }\end{array}$ & $\begin{array}{l}\text { Small aspect ratio of } 1 \mathrm{D} \\
\text { nanostructures }\end{array}$ & Relatively high aspect ratio (see Tables 1 and 2) & {$[35,36]$} \\
\hline $\begin{array}{l}\text { Template techniques } \\
\text { (i.e., Anodic Aluminum } \\
\text { Oxide, AAO and } \\
\text { subsequent deposition) }\end{array}$ & $\begin{array}{l}\text { Numerous steps of synthesis } \\
\text { (formation of template, deposition, } \\
\text { removal of the template) }\end{array}$ & $\begin{array}{l}\text { An easy-to-conduct, two-step synthesis } \\
\text { (electropolishing }+ \text { anodizing) }\end{array}$ & [59] \\
\hline Sol-gel techniques & $\begin{array}{l}\text { Multistep process, } \\
\text { time-consuming method }\end{array}$ & $\begin{array}{l}\text { Anodization can be minutes long, in order to } \\
\text { achieve a surface covered by oxide nanoneedles }\end{array}$ & {$[60]$} \\
\hline
\end{tabular}

\section{Conclusions and Challenges}

The self-organized anodization of copper allows one to obtain anodic oxides with various morphologies, including nanoneedles, nanowires, or even nanoporous structures. Furthermore, the chemical composition of the formed nanostructures can be varied using appropriate experimental conditions in anodizing and various post-treatment procedures. The literature reveals that nanostructured oxides grown on copper can contribute to glucose sensing in the presence of interfering compounds and in human blood serum. Furthermore, the nanoneedles grown by copper anodization are capable of forming superhydrophobic surfaces, including smart, $\mathrm{pH}$-responsive permeation systems. Copper anodization also contributes to renewable energy harvesting research: it enables the photocatalytic decomposition of water to hydrogen and oxygen. When the photocatalyst is made of a $\mathrm{Cu}_{2} \mathrm{O}-\mathrm{CuO}$ mixture, it can generate oxygen from water. 
The current state-of-the art review also revealed numerous challenges in copper anodization:

1. There are challenges in the formation of anodic copper oxides: generally, only $\mathrm{KOH}$ - and $\mathrm{NaOH}$-based electrolytes were used for anodizing. The Pourbaix diagram revealed many more opportunities. Thus, electrolytes in a $\mathrm{pH}$ range from ca. 7 to 11 could provide different morphologies and more uniform chemical compositions. Potassium oxalate, used as an anodizing electrolyte, shows that there is still much to explore in this field.

2. A full systemic study of the influence of the operating conditions (type of the electrolyte, voltage, time, temperature) on the morphology of the grown nanostructures has not yet been reported, though this would be beneficial for all researchers working in the field of applications of copper and cuprous oxide nanostructures. In this field, the formation of nanostructures via anodization with a diameter smaller than ca. $7 \mathrm{~nm}$, in order to observe a significant QC effect, would be also challenging.

3. There is also a demand to quantify the chemical composition of the grown nanostructures versus the operating conditions of anodization. It would be beneficial from both a fundamental point of view (understanding the mechanism of growth with hard, experimental data) and for applications in which chemical purity is crucial, such as photovoltaics.

4. In contrast to all anodic oxides, nanostructures grown by copper electrochemical oxidation are crystalline. From a fundamental point of view, investigating the crystal orientation would be important, so as to determine whether the anodization of a planar sample, in a constant electric field, induces the growth of oriented, crystalline nanowires and nanoneedles.

In summary, anodization, a relatively novel approach in copper oxides nanoengineering, allows one to obtain a variety of morphologies, thus contributing to state-of-the-art emerging applications.

Author Contributions: W.J.S. is responsible for the literature review and presenting the information in the tables. Both authors participated in the manuscript preparation; however, majority of the writing was done by W.J.S. and most of the editing was done by W.Z.M.

Acknowledgments: Wojciech J. Stępniowski cordially acknowledges financial support from the Kosciuszko Foundation in New York, NY, USA. Both authors would like to express their gratitude to the Loewy Family Foundation for the financial support through endowment at Lehigh University.

Conflicts of Interest: The authors declare no conflict of interest.

\section{References}

1. Jani, A.M.M.; Losic, D.; Voelcker, N.H. Nanoporous anodic aluminium oxide: Advances in surface engineering and emerging applications. Prog. Mater. Sci. 2013, 58, 636-704. [CrossRef]

2. Kowalski, D.; Kim, D.; Schmuki, P. $\mathrm{TiO}_{2}$ nanotubes, nanochannels and mesosponge: Self-organized formation and applications. Mater. Today 2013, 8, 235-264. [CrossRef]

3. Wierzbicka, E.; Sulka, G.D. Fabrication of highly ordered nanoporous thin Au films and their application for electrochemical determination of epinephrine. Sens. Actuator B Chem. 2016, 222, 270-279. [CrossRef]

4. Kumeria, T.; Rahman, M.M.; Santos, A.; Ferre-Borrull, J.; Marsal, L.F.; Losic, D. Nanoporous Anodic Alumina Rugate Filters for Sensing of Ionic Mercury: Toward Environmental Point-of-Analysis Systems. ACS Appl. Mater. Interfaces 2014, 6, 12971-12978. [CrossRef] [PubMed]

5. Stęniowski, W.J.; Salerno, M. Fabrication of nanowires and nanotubes by anodic alumina template assisted electrodeposition. In Manufacturing Nanostructures; One Central Press: Altrincham Cheshire, UK, 2014; pp. 321-357.

6. Santos, A.; Yoo, J.H.; Rohatgi, C.V.; Kumeria, T.; Wang, Y.; Losic, D. Realisation and advanced engineering of true optical rugate filters based on nanoporous anodic alumina by sinusoidal pulse anodization. Nanoscale 2016, 8, 1360-1373. [CrossRef] [PubMed]

7. Santos, A.; Law, C.S.; Pereira, T.; Losic, D. Nanoporous hard data: Optical encoding of information within nanoporous anodic alumina photonic crystals. Nanoscale 2016, 8, 8091-8100. [CrossRef] [PubMed] 
8. Attauri, A.C.; Huang, Z.; Belwalkar, A.; van Geertruyden, W.; Gao, D.; Misiolek, W. Evaluation of Nano-Porous Alumina Membranes for Hemodialysis Application. ASAIO J. 2009, 217-223. [CrossRef] [PubMed]

9. Law, C.S.; Santos, A.; Kumeria, T.; Losic, D. Engineered Therapeutic-Releasing Nanoporous Anodic Alumina Aluminum Wires with Extended Release of Therapeutics. ACS Appl. Mater. Interfaces 2015, 7, 3846-3853. [CrossRef] [PubMed]

10. Salerno, M.; Loria, P.; Matarazzo, G.; Tome, F.; Diaspro, A.; Eggenhoffner, R. Surface Morphology and Tooth Adhesion of a Novel Nanostructured Dental Restorative Composite. Materials 2016, 9, 203. [CrossRef] [PubMed]

11. Feng, X.; Shankar, K.; Paulose, M.; Grimes, C.A. Tantalum-Doped Titanium Dioxide Nanowire Arrays for Dye-Sensitized Solar Cells with High Open-Circuit Voltage. Angew. Chem. Int. Ed. 2009, 121, 8239-8242. [CrossRef]

12. Zhang, L.; Liu, L.; Wang, H.; Shen, S.; Chemg, Q.; Yan, C.; Park, S. Electrodeposition of Rhodium Nanowires Arrays and Their Morphology-Dependent Hydrogen Evolution Activity. Nanomaterials 2017, 7, 103. [CrossRef] [PubMed]

13. Zhang, X.; Han, F.; Shi, B.; Farsinezhad, S.; Dechaine, G.P.; Shankar, K. Photocatalytic Conversion of Diluted $\mathrm{CO}_{2}$ into Light Hydrocarbons Using Periodically Modulated Multiwalled Nanotube Arrays. Angew. Chem. Int. Ed. 2012, 51, 12732-12735. [CrossRef] [PubMed]

14. Méndez, M.; González, S.; Vega, V.; Teixeira, J.M.; Hernando, B.; Luna, C.; Prida, V.M. Ni-Co Alloy and Multisegmented Ni/Co Nanowire Arrays Modulated in Composition: Structural Characterization and Magnetic Properties. Crystals 2017, 7, 66. [CrossRef]

15. Toccafondi, C.; Zaccaria, R.P.; Dante, S.; Salerno, M. Fabrication of Gold-Coated Ultra-Thin Anodic Porous Alumina Substrates for Augmented SERS. Materials 2016, 9, 403. [CrossRef] [PubMed]

16. Nesbitt, N.; Merlo, J.M.; Rose, A.H.; Calm, Y.M.; Kempa, K.; Burns, M.J.; Naughton, M.J. Aluminum Nanowire Arrays via Directed Assembly. Nano Lett. 2015, 15, 7294-7299. [CrossRef] [PubMed]

17. Kikuchi, T.; Nishinaga, O.; Natsui, S.; Suzuki, R.O. Polymer nanoimprinting using an anodized aluminum mold for structural coloration. Appl. Surf. Sci. 2015, 341, 19-27. [CrossRef]

18. Norek, M.; Krasinski, A. Controlling of water wettability by structural and chemical modification of porous anodic alumina (PAA): Towards super-hydrophobic surfaces. Surf. Coat. Technol. 2015, 276, 464-470. [CrossRef]

19. Chien, Y.C.; Weng, H.C. A Brief Note on the Magnetowetting of Magnetic Nanofluids on AAO Surfaces. Nanomaterials 2018, 8, 118. [CrossRef] [PubMed]

20. Stepniowski, W.J.; Choi, J.; Yoo, H.; Oh, K.; Michalska-Domanska, M.; Chilimoniuk, P.; Czujko, T.; Lyszkowski, R.; Jozwiak, S.; Bojar, Z.; et al. Anodization of FeAl intermetallic alloys for bandgap tunable nanoporous mixed aluminum-iron oxide. J. Electroanal. Chem. 2016, 771, 37-44. [CrossRef]

21. Choi, Y.W.; Kim, S.; Seong, M.; Yoo, H.; Choi, J. $\mathrm{NH}_{4}$-doped anodic $\mathrm{WO}_{3}$ prepared through anodization and subsequent $\mathrm{NH}_{4} \mathrm{OH}$ treatment for water splitting. Appl. Surf. Sci. 2015, 324, 414-418. [CrossRef]

22. Kikuchi, T.; Kawashima, J.; Natsui, S.; Suzuki, R.O. Fabrication of porous tungsten oxide via anodizing in an ammonium nitrate/ethylene glycol/water mixture for visible light-driven photocatalyst. Appl. Surf. Sci. 2017, 422, 130-137. [CrossRef]

23. Zaraska, L.; Gawlak, K.; Gurgul, M.; Chlebda, D.K.; Socha, R.P.; Sulka, G.D. Controlled synthesis of nanoporous tin oxide layers with various pore diameters and their photoelectrochemical properties. Electrochim. Acta 2017, 254, 238-245. [CrossRef]

24. Wierzbicka, E.; Syrek, K.; Sulka, G.D.; Pisarek, M.; Janik-Czachor, M. The effect of foil purity on morphology of anodized nanoporous $\mathrm{ZrO}_{2}$. Appl. Surf. Sci. 2016, 388, 799-804. [CrossRef]

25. Pisarek, M.; Krajczewski, J.; Wierzbicka, E.; Holdynski, M.; Sulka, G.D.; Nowakowski, R.; Kudelski, A.; Janik-Czachor, M. Influence of the silver deposition method on the activity of platforms for chemometric surface-enhanced Raman scattering measurements: Silver films on $\mathrm{ZrO}_{2}$ nanopore arrays. Spectrochim. Acta A Mol. Biomol. Spectrosc. 2017, 182, 124-129. [CrossRef] [PubMed]

26. Park, J.; Kim, K.; Choi, J. Formation of $\mathrm{ZnO}$ nanowires during short durations of potentiostatic and galvanostatic anodization. Curr. Appl. Phys. 2013, 7, 1370-1375. [CrossRef]

27. Zaraska, L.; Mika, K.; Syrek, K.; Sulka, G.D. Formation of ZnO nanowires during anodic oxidation of zinc in bicarbonate electrolytes. J. Electroanal. Chem. 2017, 801, 511-520. [CrossRef] 
28. Yoo, J.E.; Park, J.; Cha, G.; Choi, J. Micro-length anodic porous niobium oxide for lithium-ion thin film battery applications. Thin Solid Films 2013, 531, 583-587. [CrossRef]

29. Stojadinovic, S.; Tadic, N.; Radic, N.; Stefanov, P.; Grbic, B.; Vasilic, R. Anodic luminescence, structural, photoluminescent, and photocatalytic properties of anodic oxide films grown on niobium in phosphoric acid. Appl. Surf. Sci. 2015, 355, 912-920. [CrossRef]

30. Ohta, T.; Masegi, H.; Noda, K. Photocatalytic decomposition of gaseous methanol over anodized iron oxide nanotube arrays in high vacuum. Mater. Res. Bull. 2018, 99, 367-376. [CrossRef]

31. Stepniowski, W.J.; Choi, J.; Yoo, H.; Michalska-Domanska, M.; Chilimoniuk, P.; Czujko, T. Quantitative fast Fourier transform based arrangement analysis of porous anodic oxide formed by self-organized anodization of FeAl intermetallic alloy. Mater. Lett. 2016, 164, 176-179. [CrossRef]

32. Zoolfakar, A.S.; Rani, R.A.; Morfa, A.J.; O'Mullane, A.P.; Kalantar-zadeh, K. Nanostructured copper oxide semiconductors: A perspective on materials, synthesis methods and applications. J. Mater. Chem. C 2014, 2, 5247-5270. [CrossRef]

33. Poulopoulos, P.; Baskoutas, S.; Pappas, S.D.; Garoufalis, C.S.; Droulias, S.A.; Zamani, A.; Kapaklis, V. Intense Quantum Confinement Effects in $\mathrm{Cu}_{2} \mathrm{O}$ Thin Films. J. Phys. Chem. C 2011, 115, 14839-14843. [CrossRef]

34. Musselman, K.P.; Wisnet, A.; Iza, D.C.; Hesse, H.C.; Scheu, C.; MacManus-Driscoll, J.L.; Schmidt-Mende, L. Strong Efficiency Improvements in Ultra-low-Cost Inorganic Nanowire Solar Cells. Adv. Mater. 2010, 22, E254-E258. [CrossRef] [PubMed]

35. Zhang, Q.; Zhang, K.; Xu, D.; Yang, G.; Huang, H.; Nie, F.; Liu, C.; Yang, S. CuO nanostructures: Synthesis, characterization, growth mechanisms, fundamental properties, and applications. Prog. Mater. Sci. 2014, 60, 208-337. [CrossRef]

36. Sun, S.; Zhang, X.; Yang, Q.; Liang, S.; Zhang, X.; Yang, Z. Cuprous oxide $\left(\mathrm{Cu}_{2} \mathrm{O}\right)$ crystals with tailored architectures: A comprehensive review on synthesis, fundamental properties, functional modifications and applications. Prog. Mater. Sci. 2018, 96, 111-173. [CrossRef]

37. Stepniowski, W.J.; Norek, M.; Budner, B.; Michalska-Domanska, M.; Nowak-Stepniowska, A.; Bombalska, A.; Kaliszewski, M.; Mostek, A.; Thorat, S.; Salerno, M.; et al. In-situ electrochemical doping of nanoporous anodic aluminum oxide with indigo carmine organic dye. Thin Solid Films 2016, 598, 60-64. [CrossRef]

38. Beverskog, B.; Puigdomenech, I. Revised Pourbaix Diagrams for Copper at 25 to $300{ }^{\circ}$ C. J. Electrochem. Soc. 1997, 144, 3476-3483. [CrossRef]

39. Gennero de Chiavlo, M.R.; Zerbino, J.O.; Marchiano, S.L.; Arvia, A.J. Correlation of electrochemical and elipsometric data in relation to the kinetics and mechanism of $\mathrm{Cu}_{2} \mathrm{O}$ electroformation in alkaline solutions. J. Appl. Electrochem. 1986, 16, 517-526. [CrossRef]

40. Ambrose, J.; Barrads, R.G.; Shoesmith, D.W. Investigation of copper in aqueous alkaline solutions by cyclic voltammetry. J. Electronal. Chem. Interfacial Electrochem. 1973, 47, 47-64. [CrossRef]

41. Stepniowski, W.J.; Stojadinovic, S.; Vasilic, R.; Tadic, N.; Karczewski, K.; Abrahami, S.T.; Buijnsters, J.G.; Mol, J.M.C. Morphology and photoluminescence of nanostructured oxides grown by copper passivation in aqueous potassium hydroxide solution. Mater. Lett. 2017, 198, 89-92. [CrossRef]

42. Allam, N.K.; Grimes, C.A. Electrochemical fabrication of complex copper oxide nanoarchitectures via copper anodization in aqueous and non-aqueous electrolytes. Mater. Lett. 2011, 65, 1949-1955. [CrossRef]

43. Satheesh Babu, T.G.; Ramachandran, T. Development of highly sensitive non-enzymatic sensor for the selective determination of glucose and fabrication of a working model. Electrochim. Acta 2010, 55, 1612-1618. [CrossRef]

44. Shooshtari, L.; Mohammadpour, R.; Zad, A.I. Enhanced photoelectrochemical processes by interface engineering, using $\mathrm{Cu}_{2} \mathrm{O}$ nanorods. Mater. Lett. 2016, 163, 81-84. [CrossRef]

45. Cheng, Z.; Ming, D.; Fu, K.; Zhang, N.; Sun, K. pH-Controllable Water Permeation through a Nanostructured Copper Mesh Film. ACS Appl. Mater. Interfaces 2012, 4, 5826-5832. [CrossRef] [PubMed]

46. Xiao, F.; Yuan, S.; Liang, B.; Li, G.; Pehkonen, S.O.; Zhang, T.J. Superhydrophobic CuO nanoneedle-covered copper surfaces for anticorrosion. J. Mater. Chem. A 2015, 3, 4374-4388. [CrossRef]

47. Wu, X.; Bai, H.; Zhang, J.; Chen, F.; Shi, G. Copper hydroxide nanoneedle and nanotube arrays fabricated by anodization of copper. J. Phys. Chem. B 2005, 109, 22836-22842. [CrossRef] [PubMed]

48. Wang, P.; $\mathrm{Ng}$, Y.H.; Amal, R. Embedment of anodized p-type $\mathrm{Cu}_{2} \mathrm{O}$ thin films with $\mathrm{CuO}$ nanowires for improvement in photoelectrochemical stability. Nanoscale 2013, 5, 2952-2958. [CrossRef] [PubMed] 
49. Oyarzún Jerez, D.P.; López Teijelo, M.; Ramos Cervantes, W.; Linarez Pérez, O.E.; Sánchez, J.; Pizarro, G.C.; Acosta, G.; Flores, M.; Arratia-Perez, R. Nanostructuring of anodic copper oxides in fluoride-containing ethylene glycol media. J. Electroanal. Chem. 2017, 807, 181-186. [CrossRef]

50. Wu, J.; Li, X.; Yadian, B.; Liu, H.; Chun, S.; Zhang, B.; Zhou, K.; Gan, C.L.; Huang, Y. Nano-scale oxidation of copper in aqueous solution. Electrochem. Commun. 2013, 26, 21-24. [CrossRef]

51. Caballero-Briones, F.; Palacios-Padrós, A.; Calzadilla, O.; Sanz, F. Evidence and analysis of parallel growth mechanisms in $\mathrm{Cu}_{2} \mathrm{O}$ films prepared by $\mathrm{Cu}$ anodization. Electrochim. Acta 2010, 55, 4353-4358. [CrossRef]

52. Jiang, W.; He, J.; Xiao, F.; Yuan, S.; Lu, H.; Liang, B. Preparation and Antiscaling Application of Superhydrophobic Anodized CuO Nanowire Surfaces. Ind. Eng. Chem. Res. 2015, 54, 6874-6883. [CrossRef]

53. Wan, Y.; Zhang, Y.; Wang, X.; Wang, Q. Electrochemical formation and reduction of copper oxide nanostructures in alkaline media. Electrochem. Commun. 2013, 36, 99-102. [CrossRef]

54. Zhang, Z.; Wang, P. Highly stable copper oxide composite as an effective photocathode for water splitting via a facile electrochemical synthesis strategy. J. Mater. Chem. 2012, 22, 2456-2464. [CrossRef]

55. Caballero-Briones, F.; Artes, J.M.; Diez-Perez, I.; Gorostiza, P.; Sanz, F. Direct Observation of the Valence Band Edge by in Situ ECSTM-ECTS in p-Type $\mathrm{Cu}_{2} \mathrm{O}$ Layers Prepared by Copper Anodization. J. Phys. Chem. C 2009, 113, 1028-1036. [CrossRef]

56. Shu, X.; Zheng, H.; Xu, G.; Zhao, J.; Cui, L.; Qin, Y.; Wang, Y.; Zhang, Y.; Wu, Y. The anodization synthesis of copper oxide nanosheet arrays and their photoelectrochemical properties. Appl. Surf. Sci. 2017, 412, 505-516. [CrossRef]

57. Arurault, L.; Belghith, M.H.; Bes, R.S. Manganese pigmented anodized copper as solar selective absorber. J. Mater. Sci. 2007, 42, 1190-1195. [CrossRef]

58. Zhang, Z.; Zhong, C.; Liu, L.; Teng, X.; Wu, Y.; Hu, W. Electrochemically prepared cuprous oxide film for photo-catalytic oxygen evolution from water oxidation under visible light. Sol. Energy Mater. Sol. Cells 2015, 132, 275-281. [CrossRef]

59. Khan, B.S.; Saeed, A.; Hayat, S.S.; Mukhtar, A.; Mehmood, T. Mechanism for the Formation of Cuprous Oxide Nanowires in AAO template by Electrodeposition. Int. J. Electrochem. Sci. 2017, 12, 890-987. [CrossRef]

60. Akhavan, O.; Tohidi, H.; Moshfegh, A.Z. Synthesis and electrochromic study of sol-gel cuprous oxide nanoparticles accumulated on silica thin film. Thin Solid Films 2009, 517, 6700-6706. [CrossRef] 